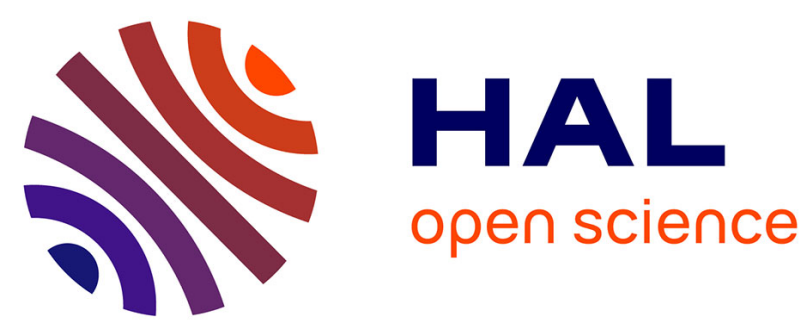

\title{
Understanding and modeling the physical processes that govern the melting of the snow cover in tropical mountain environment in Ecuador
}

Patrick Wagnon, M. Lafaysse, Y. Lejeune, L. Maisincho, M. Rojas, J.P. Chazarin

\section{To cite this version:}

Patrick Wagnon, M. Lafaysse, Y. Lejeune, L. Maisincho, M. Rojas, et al.. Understanding and modeling the physical processes that govern the melting of the snow cover in tropical mountain environment in Ecuador. Journal of Geophysical Research, 2009, 114, pp.D19113. 10.1029/2009JD012292 . insu00420849

\section{HAL Id: insu-00420849 \\ https://hal-insu.archives-ouvertes.fr/insu-00420849}

Submitted on 24 Mar 2021

HAL is a multi-disciplinary open access archive for the deposit and dissemination of scientific research documents, whether they are published or not. The documents may come from teaching and research institutions in France or abroad, or from public or private research centers.
L'archive ouverte pluridisciplinaire HAL, est destinée au dépôt et à la diffusion de documents scientifiques de niveau recherche, publiés ou non, émanant des établissements d'enseignement et de recherche français ou étrangers, des laboratoires publics ou privés. 


\title{
Understanding and modeling the physical processes that govern the melting of snow cover in a tropical mountain environment in Ecuador
}

\author{
P. Wagnon, ${ }^{1}$ M. Lafaysse, ${ }^{2}$ Y. Lejeune, ${ }^{3}$ L. Maisincho, ${ }^{4}$ M. Rojas, ${ }^{4}$ and J. P. Chazarin ${ }^{5}$
}

Received 21 April 2009; revised 18 June 2009; accepted 1 July 2009; published 10 October 2009.

[1] The ISBA/CROCUS coupled ground-snow model developed for the Alps and subsequently adapted to the outer tropical conditions of Bolivia has been applied to a full set of meteorological data recorded at $4860 \mathrm{~m}$ above sea level on a moraine area in Ecuador (Antizana 15 glacier, $0^{\circ} 28^{\prime} \mathrm{S} ; 78^{\circ} 09^{\prime} \mathrm{W}$ ) between 16 June 2005 and 30 June 2006 to determine the physical processes involved in the melting and disappearance of transient snow cover in nonglaciated areas of the inner tropics. Although less accurate than in Bolivia, the model is still able to simulate snow behavior over nonglaciated natural surfaces, as long as the modeled turbulent fluxes over bare ground are reduced and a suitable function is included to represent the partitioning of the surface between bare soil and snow cover. The main difference between the two tropical sites is the wind velocity, which is more than 3 times higher at the Antizana site than at the Bolivian site, leading to a nonuniform spatial distribution of snow over nonglaciated areas that is hard to describe with a simple snow partitioning function. Net solar radiation dominates the surface energy balance and is responsible for the energy stored in snow-free areas (albedo $=0.05)$ and transferred horizontally to adjacent snow patches by conduction within the upper soil layers and by turbulent advection. These processes can prevent the snow cover from lasting more than a few hours or a few days. Sporadically, and at any time of the year, this inner tropical site, much wetter than the outer tropics, experiences heavy snowfalls, covering all the moraine area, and thus limiting horizontal transfers and inducing a significant time lag between precipitation events and runoff.

Citation: Wagnon, P., M. Lafaysse, Y. Lejeune, L. Maisincho, M. Rojas, and J. P. Chazarin (2009), Understanding and modeling the physical processes that govern the melting of snow cover in a tropical mountain environment in Ecuador, J. Geophys. Res., 114, D19113, doi:10.1029/2009JD012292.

\section{Introduction}

[2] Mountains gather more than half of the Earth's fresh water [Weingartner et al., 2003]. In the arid and semiarid regions of the tropics and subtropics, this figure rises to more than $80 \%$, with major affects on the downstream population [Messerli, 2001]. Given the projected changes in climate [Vuille et al., 2008a], understanding the physical processes that affect the water cycle of this fragile environment is a high priority. A considerable part of the water in tropical mountains is initially stored as ice in glaciers and then gradually released over time. Tropical glaciers (almost entirely located in the Andes) act as a critical buffer against highly seasonal precipitation and their melting smoothes the seasonal variation of runoff [Kaser and Osmaston, 2002]. This regulating role of the glaciers is even more pronounced in the tropics

\footnotetext{
${ }^{1}$ IRD-LTHE-LGGE, St. Martin d'Hères, France.

${ }^{2}$ Météo-France/Centre National Recherche Meteorologique, GAMELTHE, Grenoble, France.

${ }^{3}$ CEN, Météo-France/Centre National Recherche Meteorologique, GAME, St. Martin d'Hères, France.

${ }^{4}$ Instituto Nacional de Meteorología en Hidrología, Quito, Ecuador.

${ }^{5}$ IRD-HSM, MSE, Montpellier, France.

Copyright 2009 by the American Geophysical Union. 0148-0227/09/2009JD012292
}

than at midlatitudes, because the lack of thermal seasons and the intense solar radiation prevent the buildup of a longlasting winter snow cover outside the glaciated areas [Vuille et al., 2008b].

[3] Whereas the shrinkage of tropical glaciers and its consequences on water resources downstream have been increasingly documented [e.g., Wagnon et al., 2001; Favier et al., 2004a, 2008; Francou et al., 2004; Mark and Seltzer, 2003; Juen et al., 2007], only the recent study of Lejeune et al. [2007a] addresses the problem of the snow cover outside the glaciated areas that may also affect the water supply downstream. In the outer tropics of Bolivia, characterized by one dry and one wet season during the year, radiative fluxes dominate the surface energy balance of the snow cover outside the glaciers [Lejeune et al., 2007a] as well as on glaciers [e.g., Sicart et al., 2005]. Indeed, intense solar radiation of these high-elevation, nonglaciated tropical areas is responsible for both rapid melting of the snow surface (favored by fresh snow albedo values usually not exceeding 0.8 ) and an important energy intake on bare surfaces, transferred horizontally by conduction within the upper soil layers or by heat advection in the air [Lejeune et al., 2007a]. These processes are very efficient and prevent the snow cover from lasting during the wet season, thus inducing a short time lag between precipitation events and runoff. In the wet inner 
tropics, characterized by more or less continuous precipitation throughout the year, the evolution and variability of the snow cover outside glaciated areas have not yet been studied on a local scale. The following questions remain unanswered. Is the snow cover in the inner tropics as transient as in the outer tropics? What impact can we expect on the resultant runoff? What are the physical processes driving the melting of the snow cover? This article will attempt to answer these important questions.

[4] This present study focuses on the melting of the snow cover on a moraine site located at $4860 \mathrm{~m}$ above sea level (asl) between the Antizana $15 \alpha$ and $15 \beta$ glaciers (Ecuador, $\left.0^{\circ} 28^{\prime} \mathrm{S} ; 78^{\circ} 09^{\prime} \mathrm{W}\right)$. The energy balance of the snowpack and the evolution of the snow cover are simulated using a melt model. Over recent decades, a large variety of melt models have been developed, ranging from simple temperature index models to sophisticated energy balance models [e.g., Hock, 2005; Armstrong and Brun, 2008], in a wide range of fields including hydrology, snow physics, snow monitoring and avalanche forecasting. To correctly simulate snow processes and melting, which is precisely the aim of this study, a sophisticated model is required including a detailed snow energy budget and representing the internal physical processes of the snowpack. The CROCUS [Brun et al., 1989, 1992], SNTHERM [Jordan, 1991] and SNOWPACK [Bartelt and Lehning, 2002] models developed to understand snow processes in midlatitude mountainous environment for operational avalanche or runoff forecasting fall into this category. These models take into account heat transfer, water transport, vapor diffusion and mechanical deformation of a phase changing snowpack. The CROCUS model, coupled with the ISBA ground model, as described by Lejeune et al. [2007a], has been chosen in this study for various reasons. First, model intercomparisons conducted during the snowMIP project showed that the CROCUS model stands among the most physical melt models and is able to simulate melting and heat transfers with reasonable accuracy in an Alpine environment [Etchevers et al., 2004]. Second, it has been already successfully applied in the outer tropics [Lejeune et al., 2007a] and this study presented the occasion to test it in a wetter tropical environment. In summary, the objective of applying this model to a moraine area in Ecuador was to assess its performance and above all, to provide insight into the physics and energy budget of this high-altitude tropical snowpack.

[5] In this study, we use a detailed and comprehensive set of meteorological data available from two automatic weather stations, one located on the moraine at $4860 \mathrm{~m}$ asl (hereinafter referred as AWSm) and the other on the Antizana $15 \alpha$ glacier at $4900 \mathrm{~m}$ asl (hereinafter referred as AWSg). The site, the measurement instruments, the climatic conditions and the model are described in section 2. Results will be presented in section 3 together with a sensitivity analysis of input data and model parameters. Finally, a discussion and some conclusions focusing on the physical processes responsible for the fast melting of this transient tropical snow cover will be provided.

\section{Site Description, Data, Climatic Conditions, and Method}

\subsection{Site Description}

[6] The Antizana is an ice-covered stratovolcano located in the eastern Cordillera of Ecuador (see Favier et al. [2004b,
Figure 1] for the precise location of this volcano and an orientation map of the Antizana $15 \alpha$ and $15 \beta$ glaciers showing the monitoring network). AWSm is located midway between the NW oriented side by side $15 \alpha$ and $15 \beta$ snouts at $4860 \mathrm{~m}$ asl on the moraine made of heterogeneous volcanic material including, in the top meters, roughly $40 \%$ stones and $60 \%$ soil, the latter made up of $70 \%$ sand, $10 \%$ clay and $20 \%$ very thin silt mostly of a dark color and free of vegetation. Figure 1 is a photograph of AWSm showing the horizontal terrace that has been excavated in the $15^{\circ}$ slope of the moraine to install the instruments. AWSg is set up in the middle of the ablation zone of the Antizana $15 \alpha$ glacier close to its axis on an approximately $10^{\circ}$ slope at $4900 \mathrm{~m}$ asl. The location and a detailed description of this station can be found in the work of Favier et al. [2004b].

\subsection{Experimental Setting and Data Treatment}

[7] Table 1 lists the AWSm sensors. The meteorological variables are recorded as half-hourly means with a 10 -s time step, except for wind direction (instantaneous values every $30 \mathrm{~min}$ ) and precipitation (cumulative sum every $10 \mathrm{~min}$ ). The entire data set comprises a period of more than 1 year (16 June 2005-30 June 2006). Complementary observations (cloud cover, cloud types, snow depth and density, crystal type of snowfalls and snow cover, precipitation phase, soil characteristics, sky view factors, and spatial variability of the snow cover) were carried out during field visits conducted roughly every 15 days throughout the studied period and during specific extensive field trips made in March-April 2008 (17 days in total). An automatic camera taking daily pictures showing the Antizana $15 \alpha$ and $15 \beta$ snouts and the surrounding moraines provide irregular estimations (depending on the visibility) of the spatial distribution of the snow cover.

[8] With the harsh conditions of the Ecuadorian Andes (high altitude, high moisture) the data set has various gaps due to power problems or sensor breakdowns, which have to be filled because the simulations need continuous records of meteorological variables. For incident solar radiation, wind velocity, air temperature and relative humidity, for gaps not exceeding a few hours (usually $2-5$ hours), an interpolation was carried out between the values on either side of the gap. For longer gaps, data were reconstructed using measurements from AWSg, applying a linear regression function calculated when both data sets (on the moraine and on the glacier) were available ( $\mathrm{r}^{2}$ always higher than 0.85$)$. In some nights the wind vanes of both AWSm and AWSg were blocked by ice or rime and the data was interpolated over periods of 510 hours. The percentages of reconstructed data over the whole data set are $0.4 \%$ for incident solar radiation, $0.5 \%$ for temperature and relative humidity and $2.4 \%$ for wind speed.

[9] Since precipitation is a crucial variable for snow cover modeling, special attention has been paid to this data set. Precipitation is continuously measured at the Antizana site using two gauges: the Geonor sensor using a weighing device and the Davis bucket-type gauge. As opposed to the Davis gauge for which the bucket does not properly tip for snow, the Geonor sensor is suitable for both solid and liquid precipitation measurements. Owing to overfilling, the Geonor precipitation record suffers from an important gap from 25 January to 9 February 2006, during which one of the main snowfall events of the period occurred. Total amounts of precipitation 


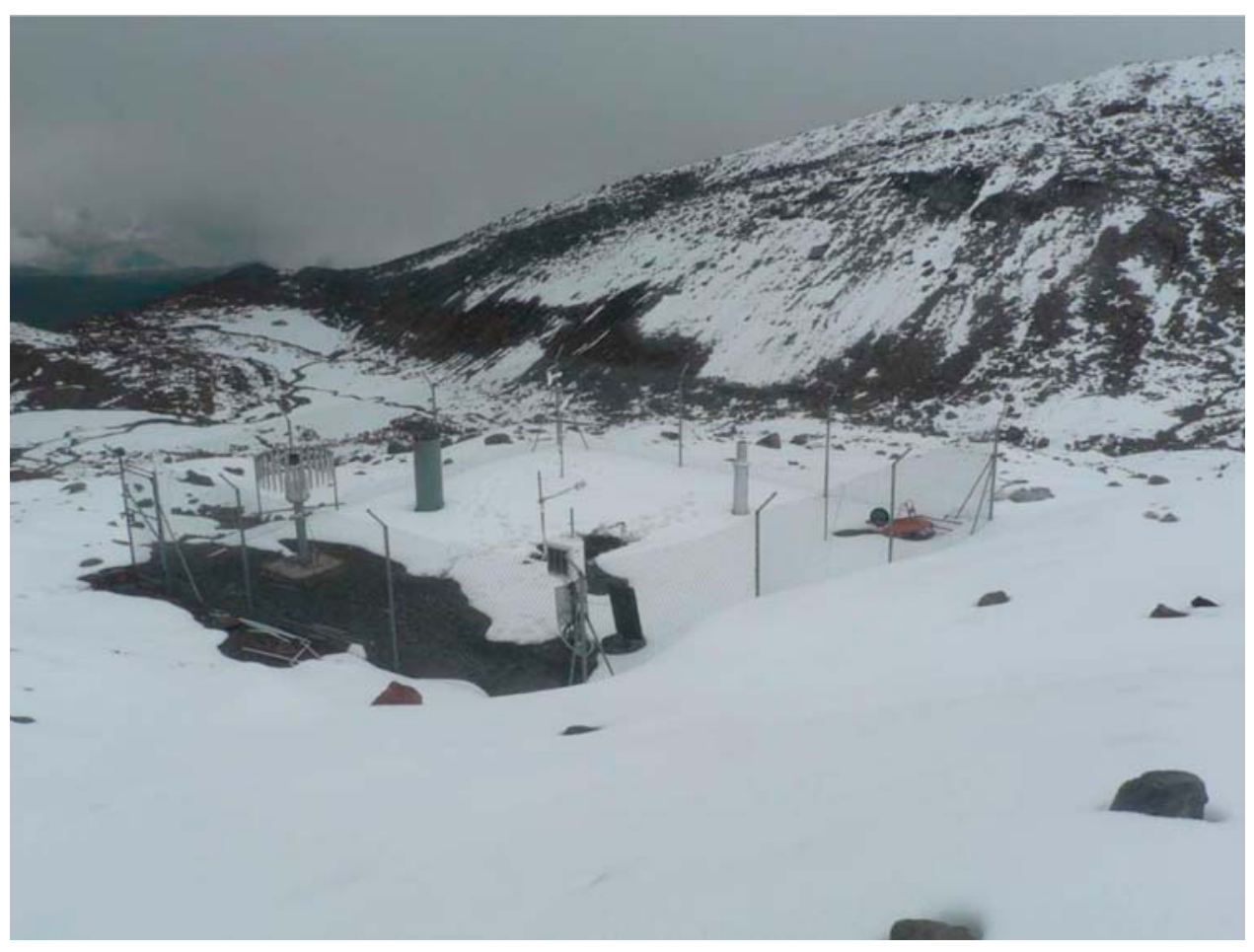

Figure 1. Photograph of Antizana 15 AWSm on 28 February 2008, taken by L. Maisinsho.

over the gap period have been estimated by comparison with the Davis gauge, applying the linear regression function between the Geonor and the Davis monthly precipitation amounts $\left(r^{2}=0.88, n=10\right.$ months). Then the reconstructed amount was distributed over the gap period according to snow depth variations recorded by the ultrasonic sensor (indicating the exact time and the intensity of snowfall events), and to the Davis gauge (giving the amount) (Table 1). For rain events (no variation in snow depth), the Davis measurement gives the exact timing of the precipitation and the amount is calculated with the Geonor-Davis regression function. For snow events, a time delay due to melting is observed between the snowfall event and the tipping of the bucket. Consequently the precipitation amount measured by the Davis gauge was readjusted in time according to snow depth changes. Once the Geonor data set was appropriately reconstructed, the correction proposed by Forland et al. [1996], depending on air temperature and wind velocity, was applied as in the work of Lejeune et al. [2007b] to take into account the difficulty of the gauge to properly collect solid precipitation in a windy environment (precipitation is systematically underestimated). Although this correction was not significant at the Charquini site [Lejeune et al., 2007b], it is important at the Antizana site due to higher wind speed, resulting in a $51 \%$ increase of the total amount of precipitation for the measurement period (total of $2163 \mathrm{~mm}$ water equivalent (mm w.e.) instead of $1433 \mathrm{~mm}$ w.e. collected in the Geonor gauge). For specific snowfalls, the corrected amount of precipitation recorded by the Geonor gauge was compared to direct field measurements (snow depth and density), confirming that a correction was required. However, the $51 \%$ increase resulting from the applied correction overestimates the amount of precipitation, probably because this correction relationship was derived from a totally different environment (Scandinavia). Moreover, precipitation gauges are located on a flat terrace excavated in the moraine slope, inducing additional turbulence that disturbs snow collection. In spite of all the efforts made to obtain the best data set (various sensor types, wind correction, and comparison with field measurements),

Table 1. List of AWSm Sensors Installed at $4860 \mathrm{~m}$ asl on the Antizana 15 Moraine

\begin{tabular}{|c|c|c|}
\hline Quantity & Sensor Type (height $(\mathrm{m}))$ & Accuracy \\
\hline Precipitation $\left(\mathrm{kg} \mathrm{m}^{-2}\right)$ & Geonor T-200B $(1.83 \mathrm{~m})$, Davis rain collector II $(1.4 \mathrm{~m})$, Totalizer $(1.3 \mathrm{~m})$ & $\pm 0.110^{-3} \pm 0.210^{-3}$ \\
\hline Air temperature $\left({ }^{\circ} \mathrm{C}\right)$ & Vaisala HPM45C, ventilated $(1.6 \mathrm{~m})$ & \pm 0.2 \\
\hline Relative humidity (\%) & Vaisala HPM45C, ventilated (1.6 m) & \pm 2 on $[0-90] \pm 3$ on $[90-100]$ \\
\hline Wind speed $\left(\mathrm{m} \mathrm{s}^{-1}\right)$ & Young $05103(2.17 \mathrm{~m})$ & \pm 0.3 \\
\hline Wind direction (deg) & Young $05103(2.17 \mathrm{~m})$ & \pm 3 \\
\hline $\begin{array}{l}\text { Incident and reflected } \\
\text { short-wave radiation }\left(\mathrm{W} \mathrm{m}^{-2}\right)\end{array}$ & Kipp and Zonen CM3 $(1 \mathrm{~m}), 0.305<\lambda<2.810^{-6} \mathrm{~m}$ & $\pm 10 \%$ on the daily sum \\
\hline $\begin{array}{l}\text { Incoming and outgoing } \\
\text { long-wave radiation }\left(\mathrm{W} \mathrm{m}^{-2}\right)\end{array}$ & Kipp and Zonen CG3 $(1 \mathrm{~m}), 5<\lambda<5010^{-6} \mathrm{~m}$ & $\pm 10 \%$ on the daily sum \\
\hline Ground temperature $\left({ }^{\circ} \mathrm{C}\right)$ & Cu-Cst Thermocouples $(-0.03,-0.10$, and $-0.30 \mathrm{~m})$ & \pm 0.2 \\
\hline Ground flux $\left(\mathrm{W} \mathrm{m}^{-2}\right)$ & Hukseflux HFP01 ( $-0.03 \mathrm{~m})$ & $60 \mu \mathrm{V} / \mathrm{W} \mathrm{m}^{-2}$ \\
\hline Accumulation/ablation $\left(10^{-2} \mathrm{~m}\right)$ & Ultrasonic Campbell SR50 (1.31 m) & $\pm 0.01 \mathrm{~m}$ \\
\hline
\end{tabular}


Table 2. Mean Values (or Total Precipitation) of the Various Meteorological Variables Over the Measurement Periods for Charquini AWS $\left(16^{\circ} 17^{\prime} \mathrm{S} ; 68^{\circ} 32^{\prime} \mathrm{W}, 4795 \mathrm{~m}\right.$ asl $)$ and Antizana AWSm $\left(0^{\circ} 28^{\prime} \mathrm{S} ; 78^{\circ} 09^{\prime} \mathrm{W} ; 4860 \mathrm{~m} \text { asl }\right)^{\mathrm{a}}$

\begin{tabular}{lcc}
\hline \multicolumn{1}{c}{ Quantity } & Charquini AWS (14 May 2002-15 Jul 2003) & Antizana AWSm (16 Jun 2005-30 Jun 2006) \\
\hline Precipitation $\left(\mathrm{kg} \mathrm{m}^{-2}\right)$ & 1302 & 2163 \\
Snow $\left(\mathrm{kg} \mathrm{m}^{-2}\right)$ & 924 & 1885 \\
Rain $\left(\mathrm{kg} \mathrm{m}^{-2}\right)$ & 378 & 278 \\
Air temperature $\left({ }^{\circ} \mathrm{C}\right)$ & 1.65 & 1.11 \\
Relative humidity (\%) & 68.7 & 77.8 \\
Wind speed $\left(\mathrm{m} \mathrm{s}^{-1}\right)$ & 1.3 & 4.4 \\
Incident short-wave radiation $\left(\mathrm{W} \mathrm{m}^{-2}\right)$ & 198 & 188 \\
Incoming long-wave radiation $\left(\mathrm{W} \mathrm{m}^{-2}\right)$ & 276 & 283 \\
\hline
\end{tabular}

${ }^{\mathrm{a}}$ For Charquini, see Lejeune et al. [2007a].

precipitation records are likely lacking in accuracy and slightly overestimated, especially for the gap period. The precipitation phase (liquid or solid) is evaluated using air temperature $\left(T_{\text {air }}\right)$ thresholds: if $T_{\text {air }} \leq-1^{\circ} \mathrm{C}$, precipitation is snow; if $T_{\text {air }} \geq+3^{\circ} \mathrm{C}$, precipitation is rain; and if $-1{ }^{\circ} \mathrm{C}<$ $T_{\text {air }}<+3^{\circ} \mathrm{C}$, an empirical relationship involving $P$ (proportion of snow versus rain where $P=1$ if only snow and 0 if only rain) and $T_{\text {air }}$ has been derived from the Lejeune et al. [2007b] algorithm based on a number of variables (albedo, ground heat flux and surface and air temperature) and their changes with time. This relationship is expressed as follows:

$$
\begin{aligned}
P= & -0.0273 T_{\text {air }}^{5}+0.1606 T_{\text {air }}^{4}-0.1653 T_{\text {air }}^{3}-0.3053 T_{\text {air }}^{2} \\
& -0.0145 T_{\text {air }}^{2}+0.9927 .
\end{aligned}
$$

During field trips conducted in March-April 2008, rain and snowfall events were regularly observed at the Antizana site. The discrimination between snow and rain given by the above relationship agrees fairly well with observations.

\subsection{Climatic Conditions}

[10] The mean values of the recorded meteorological variables over the measurement period are displayed in Table 2 together with the values collected at Charquini site $\left(16^{\circ} 17^{\prime} \mathrm{S}\right.$; $68^{\circ} 32^{\prime} \mathrm{W}, 4795 \mathrm{~m}$ asl), Bolivia, between 14 May 2002 and 15 July 2003 [Lejeune et al., 2007a]. Figure 2 shows their daily averages.

[11] The inner tropics of Ecuador are characterized by homogenous climatic conditions throughout the year, with more or less constant air temperature, humidity, incident solar radiation and incoming long-wave radiation. Ecuador is always under the influence of the equatorial easterlies in the upper troposphere [Vuille et al., 2000; Garreaud et al., 2009], allowing a near-surface moisture influx from the east and bringing significant precipitation every month with some variations from year to year, especially in the eastern Cordillera. The main noticeable seasonal variation concerns wind speed which is high between May and September as already observed by Favier et al. [2004b]. During this windy period, incident solar radiation is also slightly higher.

[12] The Charquini site is located in the outer tropics characterized by one dry and one wet season during the year. On one hand, the winter dry season (May-August) is produced by the northward displacement of the mid- and upper-tropospheric westerlies that prevent moisture influx from the east. On the other hand, the rainy season (OctoberMarch) is a result of the seasonal expansion of the equatorial easterlies in the upper troposphere, allowing a near-surface moisture influx from the east due to turbulent entrainment of easterly momentum over the Andean ridge [e.g., Garreaud, 2000]. Looking at mean values over the measurement periods, the Antizana and Charquini sites are roughly similar even though the Ecuadorian climate is wetter (higher precipitation and relative humidity). The main difference is the wind velocity which is more than 3 times higher at the Antizana AWSm than at the Charquini site (Table 2).

\subsection{Method: Model Description and Parameterization}

[13] The CROCUS snow model [Brun et al., 1989, 1992], the ISBA ground model [e.g., Noilhan and Planton, 1989; Boone et al., 2000] and the coupled CROCUS/ISBA model [Bouilloud and Martin, 2006] have been extensively described by Lejeune et al. [2007a] with the specific parameterization used for a tropical site. The coupled model combines all the characteristics of the two models. It is a one-dimensional multilayer physical model which explicitly evaluates mass and energy exchanges between the soil layers, the snowpack and the low-level atmosphere at 5-min time steps in the soil and at 15-min time steps in the snow as a function of meteorological conditions, including turbulent heat and moisture surface transfers, ground heat flux, and land subsurface processes. It computes heat transfer within the soil and snowpack, and also the grain types (from which surface albedo is derived, according to optical diameter), snow temperature, density, and the liquid-water content of each snow layer.

[14] Soil properties are derived from measured sand and clay proportions $(70 \%$ sand, $10 \%$ clay) using the standard ISBA parameterization. The corresponding values of the dry soil density, volumetric porosity, and water saturated thermal conductivity are $1890 \mathrm{~kg} \mathrm{~m}^{-3}, 30 \%$ and $2.66 \mathrm{~W} \mathrm{~m}^{-1} \mathrm{~K}^{-1}$, respectively. The bare soil albedo measured at the AWSm site is 0.05 , and ground emissivity is assumed to be 0.95 [Noilhan and Planton, 1989]. The soil surface roughness lengths for momentum, temperature and humidity are assumed to be the same and equal to $2.510^{-2} \mathrm{~m}$ for soil [Liston and Sturm, 1998 ] and $2.910^{-3} \mathrm{~m}$ for snow, respectively (resulting from a

Figure 2. Variation in the daily mean values of (a) air temperature $\left(T_{\text {air }}\right)$, relative humidity $(\mathrm{RH})$, (b) incident short-wave radiation $\left(\mathrm{SW}_{\mathrm{inc}}\right)$, incoming long-wave radiation $\left(\mathrm{LW}_{\mathrm{inc}}\right)$, (c) daily cumulative solid (shaded histograms) and liquid precipitation (bold histograms) and wind velocity recorded over the measurement period 16 June 2005 to 30 June 2006 at the Antizana 15 AWSm site (4860 m above sea level (asl)). 

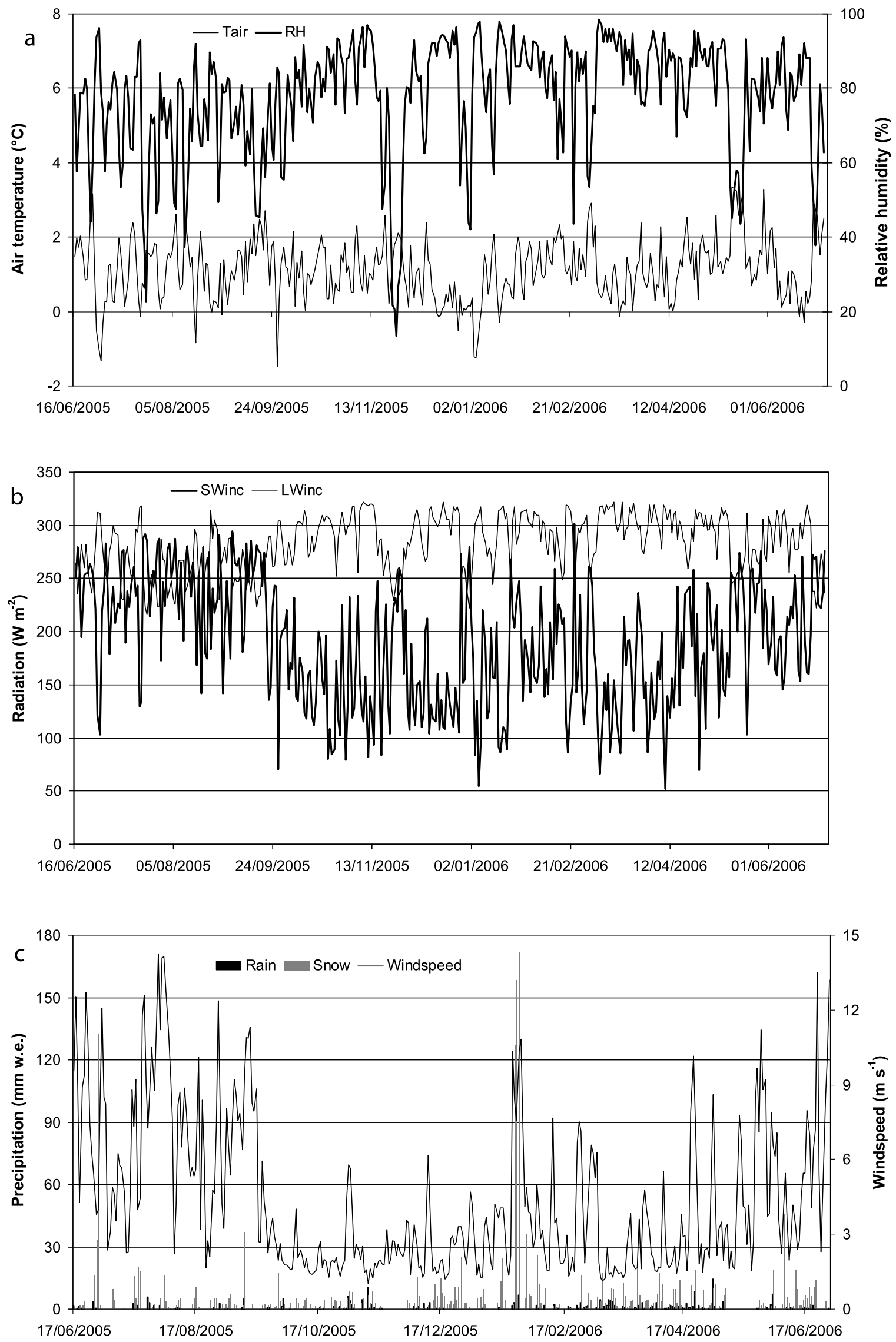

Figure 2 
Table 3. Main Characteristics of Each Model Run ${ }^{\mathrm{a}}$

\begin{tabular}{|c|c|c|c|c|c|}
\hline \multirow[b]{2}{*}{$\underline{\text { Model Run }}$} & \multicolumn{2}{|c|}{$F_{S}$} & \multicolumn{2}{|c|}{ Soil Roughness Length } & \multirow[b]{2}{*}{ Other Characteristics } \\
\hline & & & & & \\
\hline 1 & 0.1 & $1 / 3$ & 2.5 & 2.5 & $F_{S}=\operatorname{Min}\left[1,\left(h / h_{\text {crit }}\right)^{x}\right]$ \\
\hline 2 & 0.1 & $1 / 3$ & 2.5 & 0.25 & $F_{S}$ \\
\hline 3 & 0.1 & $1 / 3$ & 2.5 & 0.025 & $F_{S}$ \\
\hline 4 & 0.1 & $1 / 3$ & 1 & 0.01 & $F_{S}$ \\
\hline 5 & 0.5 & $1 / 4$ & 1 & 0.01 & $F_{S}$ \\
\hline 6 & 0.1 & $1 / 3$ & 1 & 0.01 & $F_{S \text { age }}=F_{S}-0.02 n^{\mathrm{b}}$ \\
\hline 7 & 0.1 & $1 / 3$ & 1 & 0.01 & No wind correction for precipitation data \\
\hline 8 & 0.1 & $1 / 3$ & 1 & 0.01 & Cloudiness set constant at 0.7 \\
\hline 9 & 0.1 & $1 / 3$ & 1 & 0.01 & Fresh snow $=$ round crystals, $0.5 \mathrm{~mm}$ diameter \\
\hline 10 & 0.1 & $1 / 3$ & 1 & 0.01 & Snow roughness lengths $=3 \mathrm{~cm}$ \\
\hline 11 & 0.1 & $1 / 3$ & 1 & 0.01 & Soil properties: $30 \%$ sand, $30 \%$ clay \\
\hline
\end{tabular}

${ }^{\mathrm{a}}$ The reference model run is in bold.

${ }^{\mathrm{b}}$ Variable $n=$ number of days since the last snowfall.

calibration with direct measurements of sublimation on the Antizana 15 glacier [Favier et al., 2004a, 2004b]). Lejeune et al. [2007a] show that the coupled model can accurately simulate the snow cover under tropical conditions as long as a suitable snow-ground partitioning function is included. The fraction of the ground covered by snow $\left(F_{S}\right)$ accounts for the fact that the snow cover is usually not thick enough to entirely cover the nonglaciated areas. The best parameterization of $F_{S}$ at the Charquini site is the following:

$$
F_{S}=\operatorname{Min}\left[1,\left(h / h_{\text {crit }}\right)^{x}\right]
$$

where $h$ is the snow height (in $\mathrm{m}$ ) and $h_{\text {crit }}$ and $x$ are model parameters, $h_{\text {crit }}$ being the critical snow height (in m) above which the ground is totally covered by snow. At the Charquini site, the best set of parameters, in agreement with field observations, is $0.1 \mathrm{~m}$ for $h_{\text {crit }}$ and $1 / 3$ for $x$. Snow drifting is not taken into account in the model because at the AWSm site, once deposited on the ground, the snow rapidly becomes wet due to air temperatures usually close to the melting point, which reduces snow drifting. Although a fresh-snow albedo parameterization specific to the outer tropics was used in Bolivia [Lejeune et al., 2007a], the initial parameterization developed for the Alps was preferred for this Ecuadorian site as explained in details in section 3.4.3.

\section{Results: Model Simulations and Statistical Evaluation}

[15] To simulate the evolution of the snow cover, we apply the coupled ISBA/CROCUS model and we proceed step by step, including first the snow-ground partitioning factor $F_{S}$ derived for outer tropic conditions (equation (2)), then gradually improving the model parameterization to increase its performance, and finally alternatively performing a series of model runs to test the sensitivity to the input data and assess new parameterizations. The characteristics of each model run are summarized in Table 3. All the simulations, presented for an hourly time step, were performed over the entire measurement period, but only parts of the entire period are displayed in figures corresponding to representative heavy (snow depth $>30 \mathrm{~cm}$ ) and light (snow depth $\leq 30 \mathrm{~cm}$ ) snow events. A statistical evaluation of the performance of each model run is also presented (Table 4) showing the relative difference between the simulated and measured numbers of hours with snow on the ground, the mean difference and the standard deviation between the simulated and measured snow depths for all the events, and also only for light snowfall events. Like in the work of Lejeune et al. [2007a], the dimensionless parameter diffalb (diffalb $=$ hourly mean albedo - measured bare soil albedo) has been used to indicate the presence (diffalb $>0)$ or absence $($ diffalb $=0)$ of snow on the ground during the day. There is sometimes no snow left below the $\mathrm{CM} 3$ sensor even though the ultrasonic gauge still measures a significant amount of snow (Figure 3), revealing a heterogeneous spatial distribution of the snow cover inside the AWSm area (approximately $10 \mathrm{~m} \times 10 \mathrm{~m}$ ). The Rousseau index has also been calculated for light snowfall events to test the performance of each model run to properly simulate a thin snow cover (snow or not on the ground in the daytime) (Table 4). The Rousseau index expresses the ability of a model to correctly reproduce reality [Rousseau, 1980]. This statistical index is commonly used in meteorology to compare predicted and observed data sets [e.g., Durand et al., 1998]. The Rousseau index $I$ is expressed as

$$
I=\frac{\mathrm{SO} \times \mathrm{NSNO}-\left(\frac{\mathrm{NSO}+\mathrm{SNO}}{2}\right)^{2}}{\left(\mathrm{SO}+\frac{\mathrm{NSO}+\mathrm{SNO}}{2}\right) \times\left(\mathrm{NSNO}+\frac{\mathrm{NSO}+\mathrm{SNO}}{2}\right)},
$$

where SO is the number of simulated "snow presence on ground" events that were observed, SNO the number of simulated events that were not observed, NSO the number of observed events that were not simulated and NSNO the amount of events that were neither simulated nor observed. This index varies from -1 (nil simulation) to 1 (perfect simulation). Unlike the classical indices (ratio test, threat score, etc.), the nonlinear formulation of the Rousseau index makes it more constraining and systematically penalizes biased computations. Long periods without snowfall and with bare ground have been removed to avoid artificially improving the indicated performance of the model. In all, the Rousseau index has been calculated for 1412 hours.

\subsection{Model Run 1: ISBA/CROCUS Model With $\mathbf{F}_{\mathrm{S}}$ Parameterization Used in Bolivia}

[16] Figure 3 shows the snow depths simulated by model run 1 for 1.5 months starting with a heavy snowfall (26 June- 

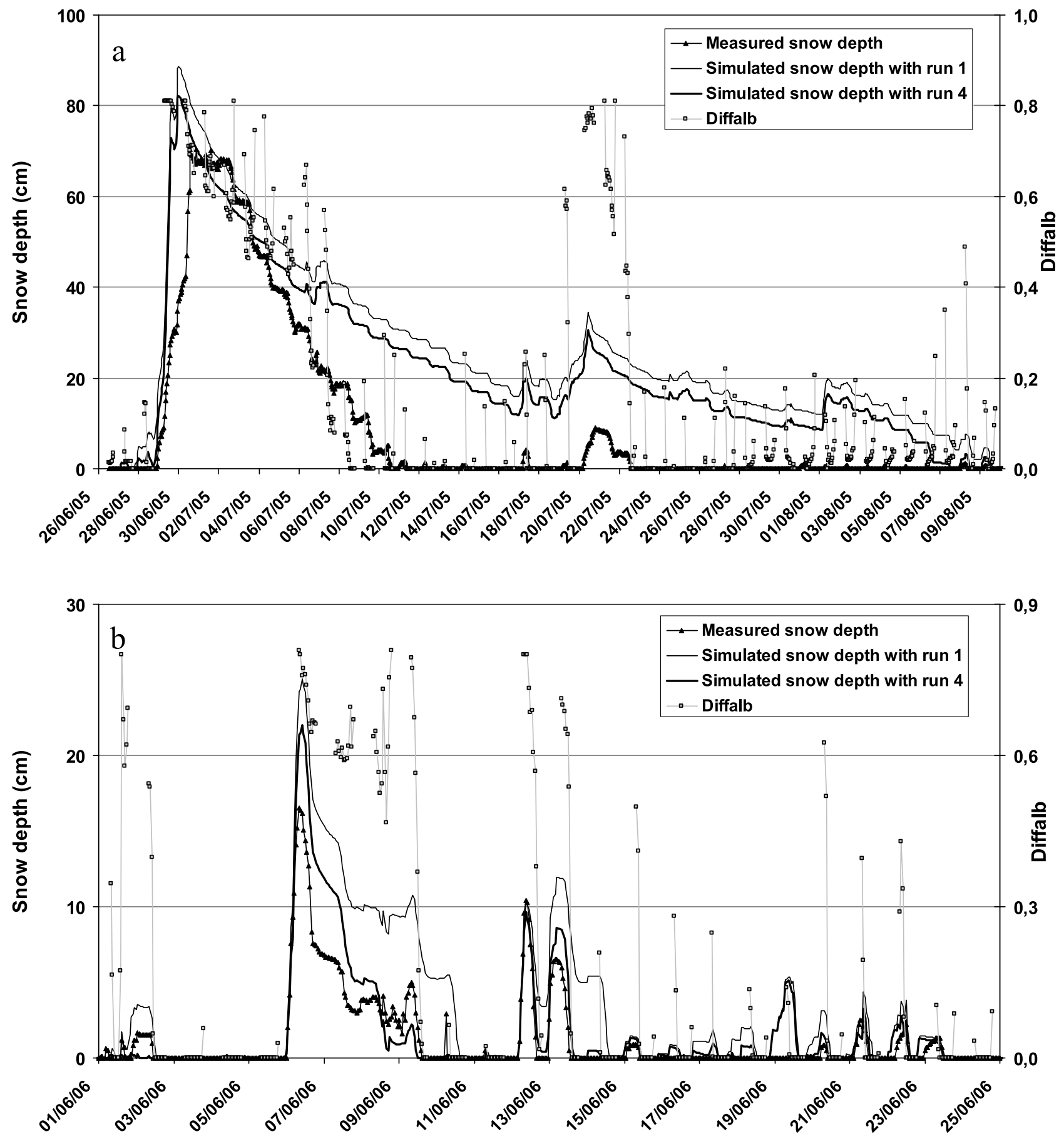

Figure 3. Simulated snow depth from model run 1 (solid line) and model run 4 (bold line) compared to measured snow depth (triangles) for two periods: (a) 26 June-9 August 2005 (heavy snowfall) and (b) 1 25 June 2006 (light snowfall). Also shown is the dimensionless parameter diffalb (squares) (diffalb $=$ hourly mean albedo - measured bare soil albedo).

9 August 2005) and for almost 1 month with regular light snowfalls (1-25 June 2006), as well as the measured snow depths and diffalb values. Table 4 gives the statistical evaluation of this model run.

[17] The model systematically overestimates the snow cover for three reasons. First, the total amount of precipitation is probably slightly overestimated as discussed in section 2.2. Second, at the beginning of the events, during the snow accumulation phase, the simulated snow depth is often too high but after a few hours or days, the difference between simulated and measured values decreases slightly due to the compaction simulated by the model (Figure 3 ). In reality, the simulated compaction during the snow accumulation phase is not strong enough to accurately reproduce the snow depth increase. If measurements could provide water equivalent, the agreement between the simulation and observations would be better. Unfortunately density measurements between 16 June 2005 and 30 June 2006 are not available, but 
Table 4. Statistical Evaluation of Each Model Run ${ }^{\mathrm{a}}$

\begin{tabular}{|c|c|c|c|c|c|}
\hline \multirow[b]{2}{*}{ Model Run } & \multirow[b]{2}{*}{ Hour Difference (\%) } & \multirow[b]{2}{*}{ Mean Difference $(\mathrm{cm})$} & \multirow[b]{2}{*}{$\mathrm{SD}(\mathrm{cm})$} & \multicolumn{2}{|c|}{ Light Snowfall Events } \\
\hline & & & & Mean Difference $(\mathrm{cm})$ & Rousseau \\
\hline 1 & 39.4 & +12.0 & 21.4 & +0.85 & 0.40 \\
\hline 2 & 36.0 & +11.1 & 20.5 & +0.24 & 0.46 \\
\hline 3 & 33.6 & +10.3 & 19.6 & -0.10 & 0.41 \\
\hline 4 & 31.7 & +9.7 & 18.9 & $-\mathbf{0 . 3 0}$ & 0.41 \\
\hline 5 & 19.4 & +6.4 & 16.5 & -0.66 & 0.33 \\
\hline 6 & 14.5 & +2.4 & 9.0 & -0.35 & 0.39 \\
\hline 7 & 10.0 & -3.7 & 12.9 & -0.71 & 0.36 \\
\hline 8 & 31.6 & +10.0 & 19.2 & -0.30 & 0.38 \\
\hline 9 & 20.4 & +4.3 & 12.0 & -0.47 & 0.35 \\
\hline 10 & 23.3 & +3.3 & 9.6 & -0.31 & 0.41 \\
\hline 11 & 31.8 & +9.7 & 18.8 & -0.36 & 0.43 \\
\hline
\end{tabular}

${ }^{a}$ Hour difference stands for the relative difference between the number of hours with snow on the ground simulated by the model and observed (according to diffalb) divided by the observed number of hours. Mean difference and standard deviation refer to the snow height simulated and measured for all events. Mean diff. and Rousseau index are calculated for light snow events. The reference model run is in bold.

measurements during the 2008 field campaign show that the computed densities during snow events are indeed usually too low. Third, and more important, the snow depletion is too slow (Table 4). This is especially the case during heavy snowfalls, where the computed snow cover lasts much longer than in reality (Figure 3a), mostly because the computed daytime melt rate is too small (during daytime, the measured snow depletion rate is often as high as $10 \mathrm{~cm} \mathrm{~d}^{-1}$ although the model barely simulates $5 \mathrm{~cm} \mathrm{~d}^{-1}$ (Figure 3a, first 10 days of July)).

\subsection{Model Runs 2-4: Other Parameterizations for the Turbulent Fluxes}

[18] Underestimation of daytime melting means that the physical processes are not well assessed by the model. A good way to check the model's ability to accurately simulate these processes is to compare measurements and simulations of the soil temperature (or of the ground flux) at various depths. Indeed soil temperature (or ground flux) results from all the energy exchanges between the atmosphere, snow and ground and within the snow and soil layers. Soil temperatures in the first tens of centimeters below the surface are effectively underestimated by the model, with a systematic $4^{\circ} \mathrm{C}$ difference and a 4- to 5-hour difference in phase at a depth of $0.3 \mathrm{~m}$ when there is no snow on the ground (Figure $4 \mathrm{a}$ ), this difference being smaller for the case with snow but still significant (approximately $1{ }^{\circ} \mathrm{C}$ ). This difference sometimes exceeds $10^{\circ} \mathrm{C}$ during the day at $0.03 \mathrm{~cm}$ below the surface (Figure $4 \mathrm{~b}$ ), and even $20^{\circ} \mathrm{C}$ at the surface (Figure $4 \mathrm{c}$ ), revealing that the modeled energy transferred to the surface layers is much too low compared to reality. Looking in detail at the surface energy balance, this is indeed the case. The turbulent fluxes are far too strong over bare soil, especially during the daytime when unstable conditions prevail at the ground surface inducing upward sensible and latent heat fluxes. This heat sink due to both turbulent fluxes is too high, reducing the energy intake at the ground surface and explaining why soil temperature is underestimated. When there is snow on the ground, stable conditions are generally observed (melting conditions) and sensible (downward) and latent (upward) heat fluxes tend to compensate each other, explaining why the temperature difference is not as high as during snow-free conditions. As a consequence three different parameterizations of soil roughness lengths for momentum $\left(z_{0 m}\right)$, temperature $\left(z_{0 T}\right)$ and humidity $\left(z_{0 q}\right)$, in accordance with Noilhan and Mahfouf [1996], have been successively tested to simulate the snow cover and the soil temperatures (model run 2: $z_{0 m}=2.5 \mathrm{~cm} ; z_{0 T}=z_{0 q}=0.25 \mathrm{~cm}$; model run 3: $z_{0 m}=2.5 \mathrm{~cm} ; z_{0 T}=z_{0 q}=0.025 \mathrm{~cm}$; model run 4: $\left.z_{0 m}=1 \mathrm{~cm} ; z_{0 T}=z_{0 q}=0.01 \mathrm{~cm}\right)($ Table 3$)$.

[19] Looking not only at snow depths but also at soil temperatures, the best results are obtained with model run 4. Corresponding snow depth and soil temperature simulations are displayed in Figures 3 and 4, respectively. The statistical evaluation of each model run is presented in Table 4. Decreasing the turbulent fluxes improves the simulation of the snow depth only for light snow events (Figure 3b and Table 4), and there is also a better agreement between measured and computed soil temperatures, but still with an overestimated daily amplitude at a depth of $0.3 \mathrm{~m}$ and a difference in phase of a few hours (Figure 4a). At a depth of $0.03 \mathrm{~m}$ and at the surface, the agreement between measured and simulated soil temperatures is improved even if the daily maximums are still too low (Figures $4 \mathrm{~b}$ and $4 \mathrm{c}$ ). In any case, the fact that the systematic difference between computed and measured 0.3-m-deep soil temperature has decreased and that the daily cycle is fairly well reproduced at various depths suggest that the model can correctly estimate the energy transfers into and between the soil and snow layers.

[20] Figure 5 shows the daily values of every heat flux of the surface energy balance over the entire measurement period: net short-wave radiation (SW), net long-wave radiation (LW), sensible $(H)$ and latent (LE) heat fluxes computed with model run 4, and the total surface energy balance. Radiative fluxes dominate the surface energy balance, but as explained above, turbulent fluxes still play an important role in the energy balance over snow-free surfaces when they are both directed upward during the daytime, thus limiting the heating of the topsoil layers. On the other hand, when there is snow on the ground, both fluxes are of opposite sign and tend to compensate each other, the downward sensible heat flux usually being slightly higher than the latent heat flux directed upward (sublimation). Consequently, to properly compute the surface energy balance, the model needs an accurate parameterization of the turbulent fluxes over bare surfaces while a rough parameterization is sufficient over snow surfaces.

\subsection{Model Runs 5 and 6: New Parameterizations of the Snow-Ground Partitioning Factor}

[21] The snow-ground partitioning factor $F_{S}$ has been implemented in the coupled ISBA/CROCUS model to take 
a

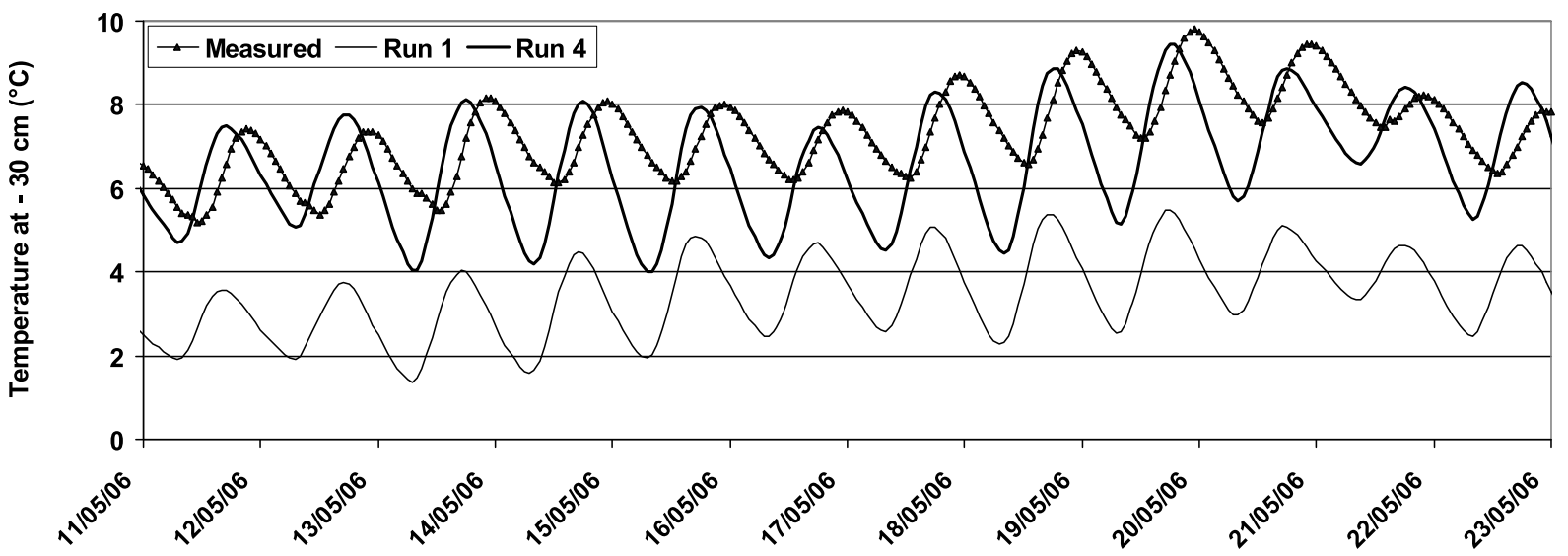

b

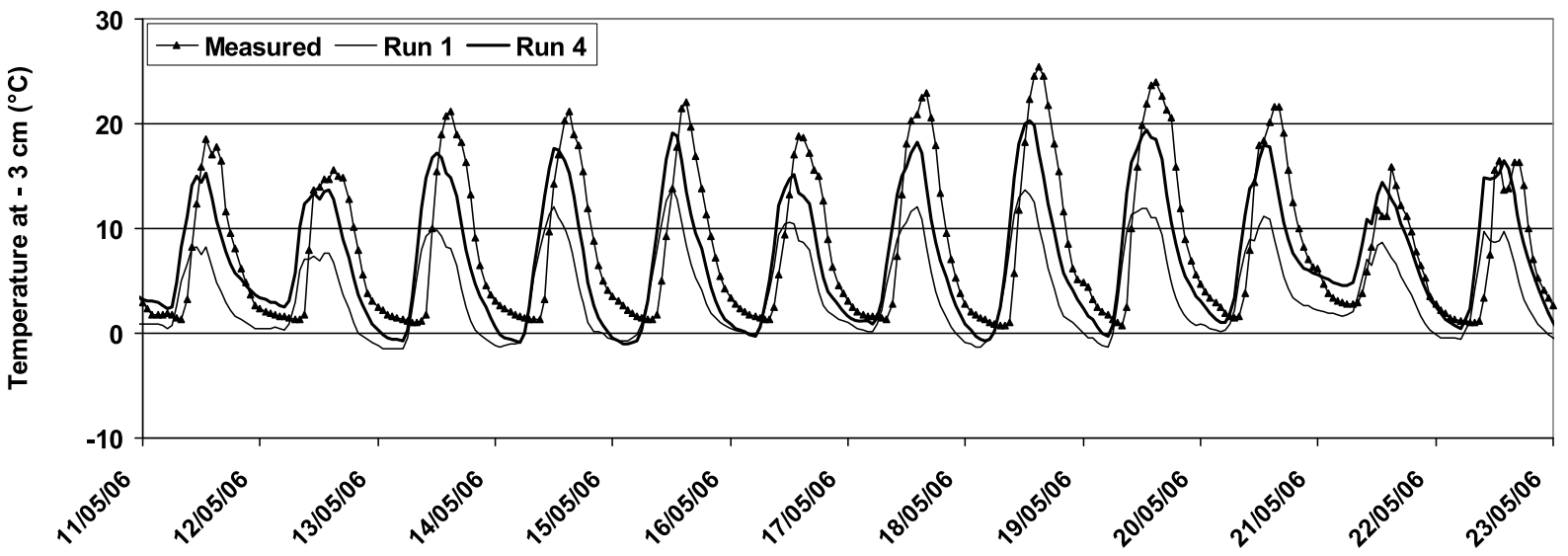

C

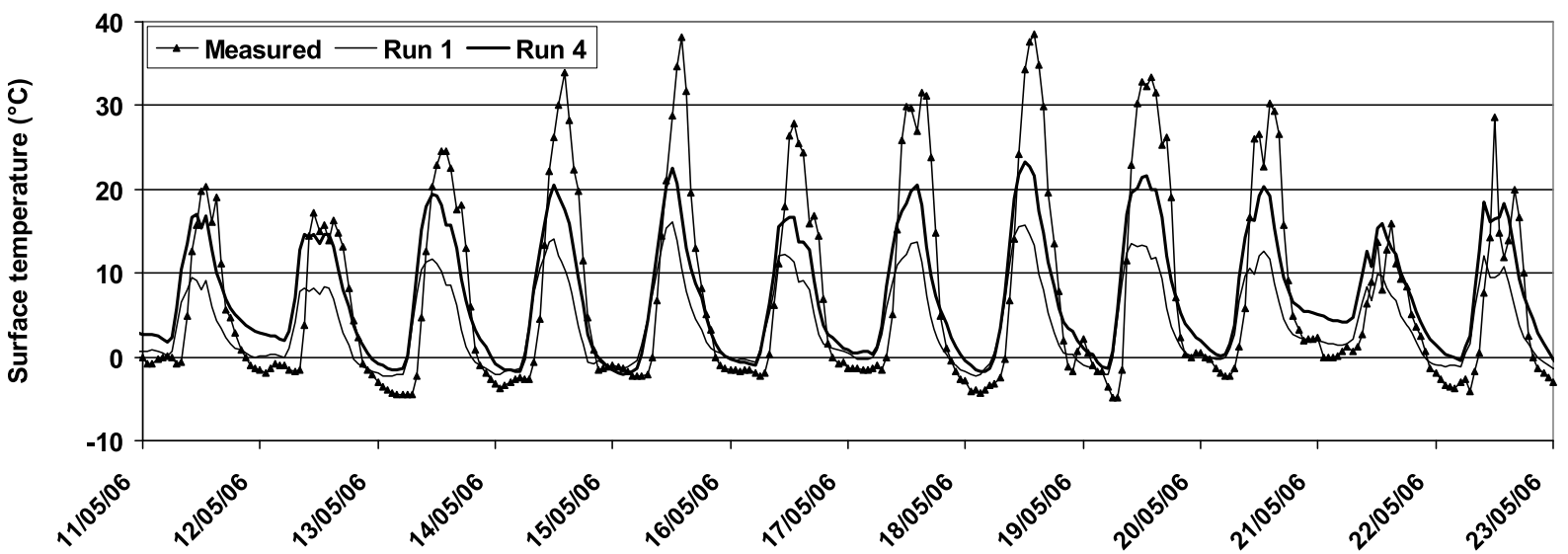

Figure 4. Measured (line with black triangles) and simulated soil temperatures from model run 1 (solid line) and model run 4 (bold line) at (a) $-30 \mathrm{~cm}$, (b) $-3 \mathrm{~cm}$, and (c) the surface, during a period with no snow on the ground (11-23 May 2006).

into account the fact that natural surfaces with a thin snow cover usually appear as a mosaic of patches of snow and bare ground. This is especially true when the wind is strong, implying a nonuniform distribution of snow. This effect is more important at the Antizana site than at the Charquini site due to stronger winds (Table 2), and field observations have shown that a few days after windy snowfalls, the moraine may be only partly covered by snow although the average snow depth is higher than 0.4 or even $0.5 \mathrm{~m}$. Therefore, in equation (2), a new set of parameters $\left(h_{\text {crit }}=0.5 \mathrm{~m}\right.$ and $x=$ 0.25 ; Table 3 ) was tested to simulate the snow depth (model run 5 in Figure 6). Results are good for heavy snowfalls (Figure 6a), showing that the model is able to properly simulate the evolution of the snow cover only if a suitable snow-ground partitioning function is added. But model run 5 results are poor for light snow events (Figure 6b and Table 4) 


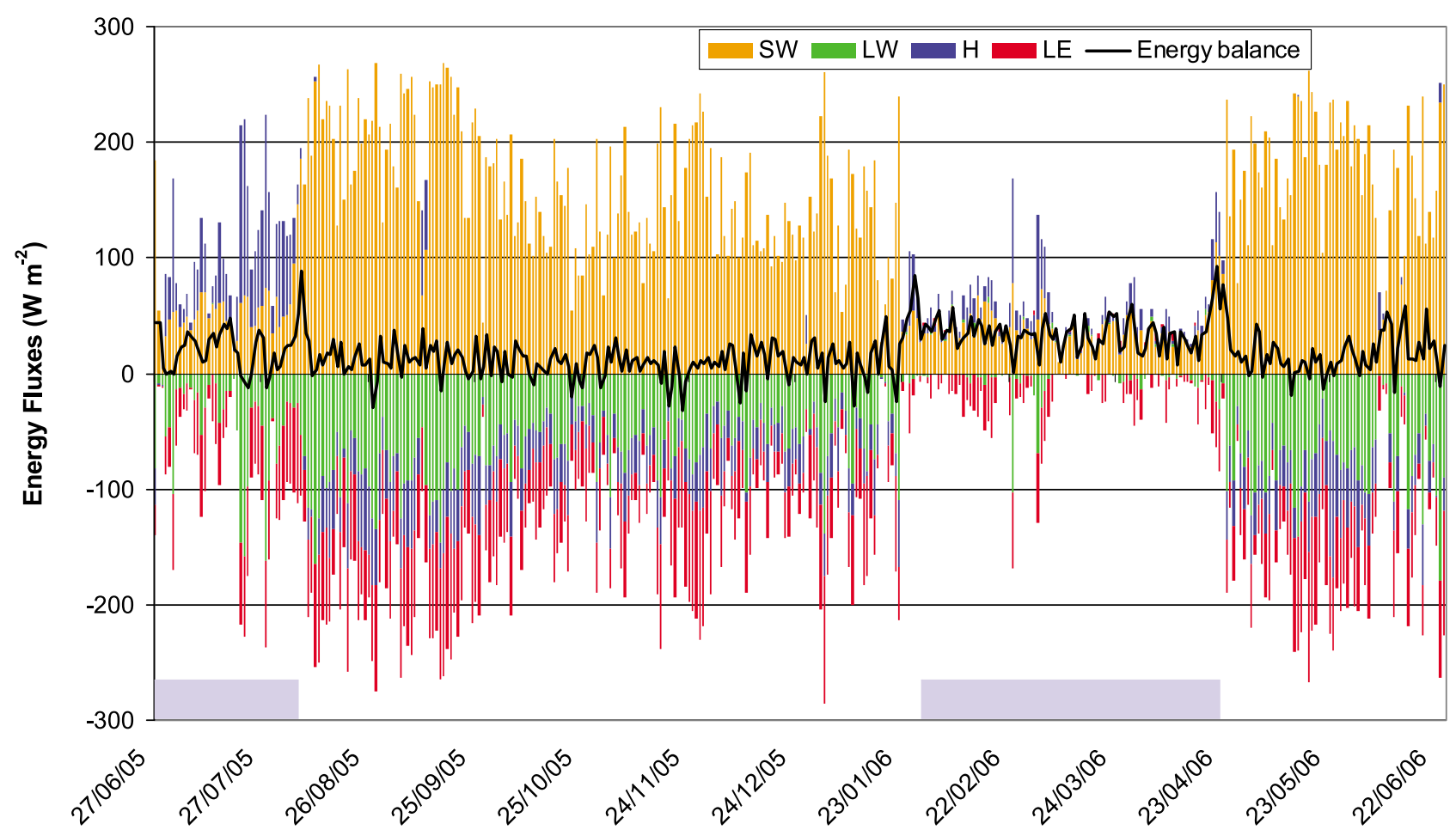

Figure 5. Daily means of net short-wave radiation SW, net long-wave radiation LW, sensible, $H$, and latent, LE, turbulent fluxes, and the surface energy balance computed with model run 4 parameterization over the entire measurement period at $4860 \mathrm{~m}$ asl at the moraine site. Also shown in shaded boxes are the long periods with snow below AWSm.

with melting that is too fast for thin snowpacks. Various formulations of $F_{S}$ may be proposed as a function of the time since the last snowfall (model run 6, Table 3), as a function of the wind speed while snow is falling, or variable according to the snow depth, bringing reasonable results for both heavy and light snow events (model run 6, Table 4). However, none of these expressions can be totally physical representative and universal because the fraction is highly dependent on local conditions such as terrain type or on-site meteorology [e.g., Pomeroy et al., 2004]. The important conclusion remains that the evolution of the snow cover cannot be adequately simulated without adding a snow-ground partitioning fraction, which means that horizontal mass and energy transfers play a crucial role in the melting and depletion of the snow cover as in Bolivia [Lejeune et al., 2007a].

\subsection{Analysis of Sensitivity With Respect to Input Data and Model Parameters}

[22] A series of simulations have been performed to assess the sensitivity of the model to precipitation (model run 7), cloudiness (model run 8), fresh snow albedo (model run 9), snow roughness lengths (model run 10), and soil properties (model run 11). Tables 3 and 4 give the main characteristics of each model run and their statistical evaluation, which has to be compared with model run 4 results, which is taken as a reference, respectively.

\subsubsection{Model Run 7: Sensitivity to Precipitation}

[23] To test the validity of the wind correction applied to precipitation data (see section 2.2), a simulation was performed using raw precipitation data without any correction (model run 7 - total precipitation over the measurement period $=1433 \mathrm{~mm}$ w.e.). Mean differences between simulated and observed snow depths are always negative (Table 4), revealing that precipitation is systematically underestimated. This wind correction is therefore required but real precipitation data are probably between these two estimates. Actually, compaction is not well simulated during snowfall and water equivalent depths are likely to be more in agreement with measurements than computed and observed snow depths (see section 3.1), suggesting that precipitation data with wind correction only slightly overestimate real precipitation amounts and are probably closer to reality than raw data. In any case, this correction is difficult to adjust to a local environment and precipitation measurements are likely to be the main source of error for snow cover simulations in this windy tropical location.

\subsubsection{Model Run 8: Sensitivity to Cloudiness}

[24] For the CROCUS model, cloudiness is derived from incoming long-wave radiation [Berliand and Berliand, 1952] but during field trips we noted large discrepancies between simulations and direct observations of the cloud cover. Therefore constant cloudiness (0.7) was implemented into the model (model run 8 - Table 3 ) to test sensitivity to this variable. The comparison of model runs 4 and 8 in Table 4 shows that the model is relatively insensitive to cloudiness and thus model results will not suffer from a poor estimate of this variable. This does not mean that cloudiness is not an important physical variable. On the contrary, it is essential because of its straightforward control of incoming long-wave radiation, which is an input parameter measured in the field. In the model, cloudiness is used to separate the incoming solar radiation into its direct and scattered components [Brun 

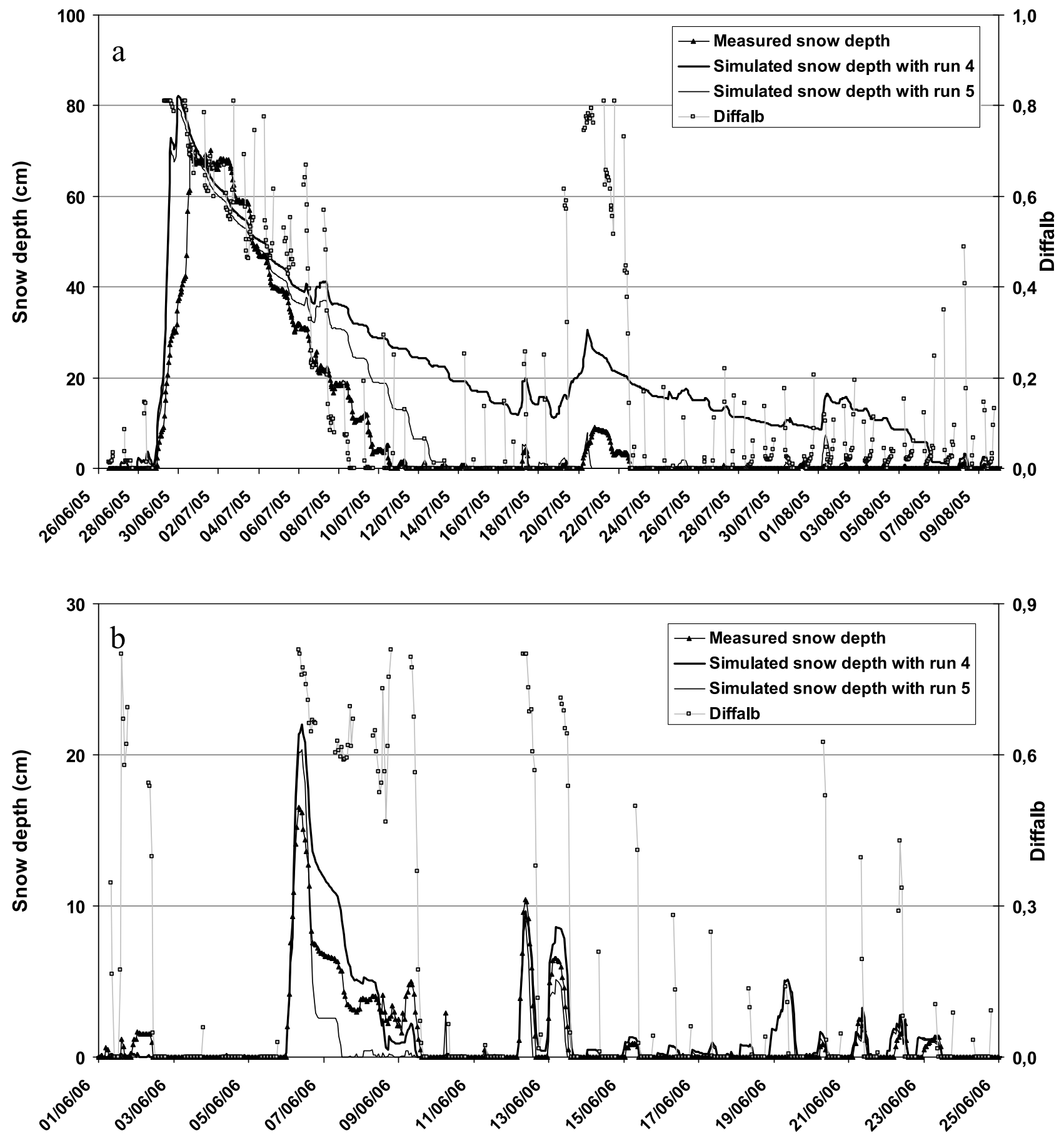

Figure 6. Simulated snow depth from model run 4 (bold line) and model run 5 (solid line) compared to measured snow depth (triangles) for two periods: (a) 26 June-9 August 2005 (heavy snowfall) and (b) 125 June 2006 (light snowfall). Also shown is the dimensionless parameter diffalb (squares) (diffalb $=$ hourly mean albedo - measured bare soil albedo).

et al., 1989], which has direct consequences on albedo. The model results are relatively insensitive to this decomposition as long as incident solar radiation is directly measured in the field, which is the case in this study.

3.4.3. Model Run 9: Sensitivity to Fresh-Snow Albedo

[25] In Bolivia, snowfalls are most often of convective origin, resulting in 1-mm-diameter round crystals of the graupel type, presenting an albedo that barely exceeds 0.8 [Lejeune et al., 2007a]. In Ecuador, during field trips, fresh- snow dendritic crystals have been regularly observed, which suggested that the CROCUS graupel-type parameterization should not be used in the simulations. To assess the impact of such a parameterization, fresh snow has been assimilated in model run 9 (Table 3 ) with round crystals of $0.5 \mathrm{~mm}$ diameter (as sometimes observed in the field) whose albedo slightly exceeds 0.8 . As shown in Table 4 , the model is very sensitive to this parameter, due to its direct impact on albedo. Reducing the fresh-snow albedo from approximately 0.9 to almost 0.8 
strongly increases melting, due to enhanced short-wave radiation absorption by the surface. For light snow events, melting is too high, which suggests that our initial parameterization using a scheme of dendritic crystals like in the Alps is more in agreement with Ecuadorian conditions, as confirmed by observations. This high sensitivity to the fresh snow parameterization, amplified by the fact that tropical conditions are characterized by intense solar radiation, reveals that the radiative budget dominates the energy exchanges at the snow surface in this specific high-elevation, low-latitude environment (Figure 5).

\subsubsection{Model Run 10: Sensitivity to Snow Roughness Lengths}

[26] Even if the radiation fluxes are the most important in the surface energy balance, a sensitivity test was performed on the turbulent fluxes. The snow surface roughness lengths were set to $310^{-2} \mathrm{~m}$ instead of $2.910^{-3} \mathrm{~m}$ which roughly doubles the latent and sensible heat fluxes (model run $10-$ Table 3). Since both fluxes are opposite and therefore tend to compensate each other above melting snow (Figure 5), the simulation results for model runs 10 and 4 are not so different. Melting is still enhanced compared to model run 4 especially during large snowfall events (Table 4 ) because $H+L E$ is most often positive, and when both turbulent fluxes double, $H+L E$ does not double but still increases significantly to bring more energy for melting. Consequently, although less sensitive than both turbulent heat fluxes, the model is moderately sensitive to the snow roughness lengths. However, the values used in model run 10 are much less realistic than model run 4 values.

\subsubsection{Model Run 11: Sensitivity to Soil Parameters}

[27] A final simulation was performed to analyze model sensitivity to soil parameters (model run 11 - Table 3 ). A soil made of $30 \%$ sand, $30 \%$ clay and $40 \%$ thin particles does not produce results significantly different from the results with the original soil (Table 4), showing that the model is not very sensitive to these parameters.

\section{Discussion and Conclusion}

[28] Although less accurate than in Bolivia, the ISBA/ CROCUS coupled ground-snow model is still able to simulate snow behavior over nonglaciated natural surfaces of the inner tropics. For light snow events, the Rousseau indexes for various simulations in Ecuador reach 0.4 (Table 4), indicating a significant correlation between simulated and observed snow depths, however they remain below the scores obtained in Bolivia where the indexes were as high as 0.6 [Lejeune et al., 2007a]. This difference in model performance is mostly explained by the fact that the Antizana site is more than 3 times as windy as the Bolivian Charquini site, with various consequences. First, in a windy mountain environment, precipitation (rain and snow) is very hard to measure in the field with a reasonable accuracy. Special attention has been paid in this study to this crucial input data, comparing different gauges and applying a correction as a function of air temperature and wind speed, however large uncertainties still remain for this data and are largely responsible for the reduced performance of the model. Second, note that the nonuniform distribution of the snow cover at this windy site makes local validation of the model more complicated than at the Charquini site. Indeed field observations and daily photo- graphs have shown that the snow depth measurements made using the ultrasonic sensor are not always representative of the whole moraine area, especially for the case of strong winds, whereas the model provides a mean spatial distribution of the snow cover. Consequently validation of model results at local scale using a single direct snow depth measurement is somewhat questionable and is likely to lead to an underestimation of the model performance. Third, with the initial parameterization, modeled turbulent fluxes over bare ground, not significant at the calm Charquini site, were too high at the Antizana site leading to an underestimation of soil temperature in the upper tens of centimeters. Consequently another parameterization of soil roughness lengths was chosen to yield better agreement between computed and measured soil temperatures. Even if the agreement is not perfect, the fact that the systematic difference decreases and that the diurnal cycle of $0.3-\mathrm{m}$-deep soil temperature is appropriately reproduced (Figure 4) serves as a validation of the energy transfers simulated by the model. This increases confidence in the ability of the model to correctly compute the physical processes responsible for the buildup and depletion of the snow cover. This also suggests that the turbulent fluxes simulated at the Charquini site were probably overestimated, but since they were not significant at this calm site, the error was not detectable. The last consequence of this windy site is the nonuniform spatial distribution of the snow cover, which is not easily described by a simple snowground partitioning fraction such as the one used at the Charquini site. Actually this fraction is very site-specific and event-dependent according to terrain type and local meteorology during snowfalls, which prevents it from being used at sites other than where it has been calibrated. Nevertheless this fraction is required to accurately reproduce the fast snow depletion observed at this tropical site.

[29] Like at the Bolivian Charquini site [Lejeune et al., 2007 a], when it is snowing on nonglaciated areas of the inner tropics, the ground remains partly covered by wet snow most of the time. At this low-latitude and high-elevation site, radiative fluxes dominate the surface energy balance (Figure 5). In daytime, the very intense incident solar radiation is not only responsible for heavy melting at the snow surface but is also efficiently absorbed by low-albedo bare ground (albedo $=0.05$ ), thereby enhancing considerably the surface temperature as well as the air temperature in the vicinity of the surface. At the same time, over snow patches, snow and near-interface ground temperatures are close to the melting point, implying a large horizontal temperature gradient not only in the top layers of the soil but also in the air immediately above the snow covered patches and the bare ground. The resulting horizontal transfers (conduction in the top layers of the soil, and advection in the air) are likely responsible for the main part of the snowmelt (through the ground heat flux at the base and the sensible heat flux at the surface of the peripheral snow cover). This process is inhibited as soon as snowfall is sufficiently intense to deposit a layer thick enough to totally cover the ground. As opposed to the outer tropics where a wet season alternates with a dry season during the year, the inner tropics experience wetter conditions throughout the year. Thus at any time of the year, a long-lasting snow cover (several days to several weeks) may occasionally buildup, inhibiting the horizontal transfers responsible for fast melting. This sporadic snow cover is then 
responsible for a significant time lag between the precipitation event and the runoff, even if it is generally only question of a few hours up to one or two days.

[30] This present study could not provide a quantitative evaluation of the horizontal energy transfers responsible for the fast melting of snow cover for two reasons. First, there was a lack of a detailed meteorological experiment as described by Granger et al. [2006], including simultaneous measurements on snow covered patches and bare ground. Second, two- or three-dimensional models are required to assess both vertical and horizontal energy exchanges, and such models were not available for our study. A further step in our study would therefore be to improve our experimental setup, which is not an easy task in this high-altitude remote environment, and to apply more sophisticated models [e.g., Essery et al., 2006].

[31] In the context of climate change and rapid shrinkage of glaciers [Vuille et al., 2008a], this study shows that tropical snow cover cannot act as a critical buffer as glaciers do. Indeed snow cover in the outer and inner tropics does not last long enough to efficiently store water and release it at a later time when water is missing. Tropical snow cover is not a substitute for glaciers in terms of the regulating role they play.

[32] Acknowledgments. The measurement program was supported by the French SO/ORE network Glacioclim (IRD and French Research Ministry). The authors are grateful for the assistance received from Instituto Nacional de Meteorología e Hidrología and Empresa Metropolitana de Alcantarillado y Agua Potable in Quito, and Ecole Nationale de Météorologie in Toulouse. This work is largely based on remarkable fieldwork, and we would like to thank all those who participated (E. Cadier, B. Francou, B. Jaramillo, and many students). We are also grateful to J. M. Willemet and L. Bouilloud; who helped to develop the coupled model, P. Chevallier and M. Szwarc, who kindly provided measurements of soil samples; and V. Favier, J. E. Sicart, P. Etchevers, E. Martin, and A. Boone, for valuable discussions that greatly improved the manuscript. Three anonymous referees who provided helpful comments on the paper are greatly acknowledged.

\section{References}

Armstrong, L., and E. Brun (2008), Snow and Climate, Physical Processes, Surface Energy Exchange and Modeling, 222 pp., Cambridge Univ. Press, New York.

Bartelt, P., and M. Lehning (2002), A physical SNOWPACK model for the Swiss avalanche warning. Part I. Numerical model, Cold Reg. Sci. Technol., 35, 123 -145, doi:10.1016/S0165-232X(02)00074-5.

Berliand, M. E., and T. G. Berliand (1952), Measurement of the effective radiation of the Earth with varying cloud amounts, Izv. Akad. Nauk SSSR, Ser. Fiz., 1, 19-27.

Boone, A., V. Masson, T. Meyers, and J. Noilhan (2000), The influence of the inclusion of soil freezing on simulations by a soil-atmosphere-transfer scheme, J. Appl. Meteorol., 39, 1544-1569, doi:10.1175/1520-0450 (2000)039<1544:TIOTIO >2.0.CO;2.

Bouilloud, L., and E. Martin (2006), A coupled model to simulate snow behavior on roads, J. Appl. Meteorol., 39, 500-516.

Brun, E., E. Martin, V. Simon, C. Gendre, and C. Coleou (1989), An energy and mass model of snow cover suitable for operational avalanche forecasting, J. Glaciol., 35, 333-342.

Brun, E., P. David, M. Sudul, and G. Brunot (1992), A numerical model to simulate snow-cover stratigraphy for operational avalanche forecasting, J. Glaciol., 38, 13-22.

Durand, Y., G. Giraud, and L. Mérindol (1998), Short-term numerical avalanche forecast used operationally at Météo-France over the Alps and Pyrenees, Ann. Glaciol., 26, 357-366.

Essery, R., R. Granger, and J. Pomeroy (2006), Boundary layer growth and advection of heat over snow and soil patches: Modelling and parameterization, Hydrol. Process., 20, 953-967, doi:10.1002/hyp.6122.

Etchevers, P., et al. (2004), Validation of the energy budget of an alpine snowpack simulated by several snow models (SnowMIP project), Ann. Glaciol., 38, 150-158, doi:10.3189/172756404781814825.

Favier, V., P. Wagnon, and P. Ribstein (2004a), Glaciers of the inner and outer tropics: A different behaviour but a common response to climatic forcing, Geophys. Res. Lett., 31, L16403, doi:10.1029/2004GL020654.
Favier, V., P. Wagnon, J. P. Chazarin, L. Maisinsho, and A. Coudrain (2004b), One-year measurements of surface heat budget on the ablation zone of Antizana glacier 15, Ecuadorian Andes, J. Geophys. Res., 109, D18105, doi:10.1029/2003JD004359.

Favier, V., A. Coudrain, E. Cadier, B. Francou, E. Ayabacha, L. Maisinsho, E. Praderio, M. Villacis, and P. Wagnon (2008), Evidence of groundwater flow on Antizana ice-covered volcano, Ecuador, Hydrol. Sci. J., 53, $278-$ 291, doi:10.1623/hysj.53.1.278.

Forland, E., P. Allerup, B. Dahlström, E. T. Elomaa, J. Perälä, P. Rissanen, H. Vedin, and F. Vejen (1996), Manual for operational correction of Nordic precipitation data, Rep. 24/96, Norske Meteorol. Inst., Oslo.

Francou, B., M. Vuille, V. Favier, and B. Caceres (2004), New evidence for an ENSO impact on low latitude glaciers: Antizana 15, Andes of Ecuador, $0^{\circ} 28^{\circ} \mathrm{S}$, J. Geophys. Res., 109, D18106, doi:10.1029/ 2003JD004484.

Garreaud, R. D. (2000), Intraseasonal variability of moisture and rainfall over South American Altiplano, Mon. Weather Rev., 128, 3337-3346, doi:10.1175/1520-0493(2000)128<3337:IVOMAR>2.0.CO;2.

Garreaud, R., M. Vuille, R. Compagnucci, and J. Marengo (2009), Presentday South American climate, Paleogeogr. Palaeoclimatol. Paleoecol., doi:10.1016/j.palaeo.2007.10.032, in press.

Granger, R. J., R. Essery, and J. W. Pomeroy (2006), Boundary layer growth over snow and soil patches: Field observations, Hydrol. Process., 20, 943-951, doi:10.1002/hyp.6123.

Hock, R. (2005), Glacier melt: A review of processes and their modelling, Prog. Phys. Geogr., 29, 362-391, doi:10.1191/0309133305pp453ra.

Jordan, R. (1991), A one-dimensional temperature model for a snow cover, Spec. Rep. 91-16, Cold Reg. Res. and Eng. Lab. U.S. Army Corps of Eng., Hanover, N. H.

Juen, I., G. Kaser, and C. Georges (2007), Modeling observed and future runoff from a glacierized tropical catchment (Cordillera Blanca, Peru), Global Planet. Change, 59, 37-48, doi:10.1016/j.gloplacha.2006.11.038.

Kaser, G., and H. Osmaston (2002), Tropical Glaciers, 207 pp., Cambridge Univ. Press, New York.

Lejeune, Y., P. Wagnon, L. Bouilloud, P. Chevallier, P. Etchevers, E. Martin, J. E. Sicart, and F. Habets (2007a), Melting of snow cover in a tropical mountain environment: Processes and melting, J. Hydrometeorol., 8, 922-937, doi:10.1175/JHM590.1.

Lejeune, Y., Y. L'Hôte, P. Etchevers, P. Wagnon, J. P. Chazarin, and P. Chevallier (2007b), Constitution d'une base de données météorologiques sur un site andin de haute altitude: Le site du Charquini, $4795 \mathrm{~m}$, Bolivie, IAHS Red Book Ser., 318, 173-185.

Liston, G. E., and M. Sturm (1998), A snow-transport model for complex terrain, J. Glaciol., 44, 498-516.

Mark, B. G., and G. O. Seltzer (2003), Tropical glacier meltwater contribution to stream discharge: A case study in the Cordillera Blanca, Peru, J. Glaciol., 49, 271-281, doi:10.3189/172756503781830746.

Messerli, B. (2001), The international year of mountains (IYM), the mountain research initiative (MRI) and PAGES, Editorial, Pages News, 9(3), 2.

Noilhan, J., and J. Mahfouf (1996), The ISBA land surface parameterization scheme, Global Planet. Change, 13, 145-159, doi:10.1016/0921-8181 (95)00043-7.

Noilhan, J., and S. Planton (1989), A simple parameterization of land surface processes for meteorological models, Mon. Weather Rev., 117, 536549, doi:10.1175/1520-0493(1989)117<0536:ASPOLS>2.0.CO;2.

Pomeroy, J., R. Essery, and B. Toth (2004), Implications of spatial distributions of snow mass and melt rate for snow-cover depletion: Theoretical considerations, Ann. Glaciol., 38, 195-201, doi:10.3189/172756404781814744.

Rousseau, D. (1980), A new skill score for the evaluation of yes/no forecasts. In Proceedings of the WMO Symposium on Probabilistic and Statistical methods in Weather Forecasting (Sept. 1980) Nice, pp. 167-174, World Meteorological Organization, Geneva, Switzerland.

Sicart, J. E., P. Wagnon, and P. Ribstein (2005), Atmospheric controls on the heat balance of Zongo Glacier $\left(16^{\circ} \mathrm{S}\right.$, Bolivia), J. Geophys. Res., 110, D12106, doi:10.1029/2004JD005732.

Vuille, M., R. S. Bradley, and F. Keimig (2000), Climate variability in the Andes of Ecuador and its relation to tropical Pacific and Atlantic sea surface temperature anomalies, J. Clim., 13, 2520-2535, doi:10.1175/ 1520-0442(2000)013<2520:CVITAO $>2.0 . \mathrm{CO} ; 2$.

Vuille, M., B. Francou, P. Wagnon, I. Juen, G. Kaser, B. Mark, and R. Bradley (2008a), Climate change and tropical Andean glaciers-past, present and future, Earth Sci. Rev., 89, 79-96, doi:10.1016/j.earscirev. 2008.04.002.

Vuille, M., G. Kaser, and I. Juen (2008b), Glacier mass balance variability in the Cordillera Blanca, Peru and its relationship with climate and the large-scale circulation, Global Planet. Change, 62, 14-28, doi:10.1016/ j.gloplacha.2007.11.003.

Wagnon, P., P. Ribstein, B. Francou, and J. E. Sicart (2001), Anomalous heat and mass budget of Zongo Glacier, Bolivia during the 1997-98 El Niño year, J. Glaciol., 47, 21-28, doi:10.3189/172756501781832593. 
Weingartner, R., M. Barben, and M. Spreafico (2003), Floods in mountain areas-an overview based on examples from Switzerland, J. Hydrol. Amsterdam, 282, 10-24, doi:10.1016/S0022-1694(03)00249-X.

J. P. Chazarin, IRD-HSM, MSE, BP 64501, F-34394 Montpellier CEDEX, France.

M. Lafaysse, Météo-France/Centre National Recherche Meteorologique, GAME-LTHE, BP 53, F-38041 Grenoble CEDEX 9, France.
Y. Lejeune, CEN, Météo-France/Centre National Recherche Meteorologique, GAME, 1441 rue de la Piscine, F-38400 St. Martin d'Hères CEDEX, France.

L. Maisincho and M. Rojas, Instituto Nacional de Meteorología en Hidrología, Casilla 17-12-857, Quito, Ecuador.

P. Wagnon, IRD-LTHE-LGGE, BP 96, F-38402 St Martin d'Hères CEDEX, France. (patrick@lgge.obs.ujf-grenoble.fr) 